\title{
Glucose or diabetes activates p38 mitogen-activated protein kinase via different pathways
}

\author{
Masahiko Igarashi, Hisao Wakasaki, Noriko Takahara, Hidehiro Ishii, Zhen-Y Jiang, \\ Teruaki Yamauchi, Koji Kuboki, Matthias Meier, Christopher J. Rhodes, \\ and George L. King
}

Research Division, Joslin Diabetes Center, Harvard Medical School, Boston, Massachusetts 02215, USA

Address correspondence to: George L. King, Joslin Diabetes Center, Section on Vascular Cell Biology, One Joslin Place, Boston, Massachusetts 02215, USA. Phone: (617) 732-2622; Fax: (617) 732-2637; E-mail: Kingg@JosLab.Harvard.edu

Received for publication March 5, 1998, and accepted in revised form December 1, 1998.

\begin{abstract}
Hyperglycemia can cause vascular dysfunctions by multiple factors including hyperosmolarity, oxidant formation, and protein kinase $\mathrm{C}$ (PKC) activation. We have characterized the effect of hyperglycemia on p38 mitogen-activated protein ( $\mathrm{p} 38$ ) kinase activation, which can be induced by oxidants, hyperosmolarity, and proinflammatory cytokines, leading to apoptosis, cell growth, and gene regulation. Glucose at $16.5 \mathrm{mM}$ increased $\mathrm{p} 38$ kinase activity in a time-dependent manner compared with $5.5 \mathrm{mM}$ in rat aortic smooth muscle cells (SMC). Mannitol activated p38 kinase only at or greater than $22 \mathrm{mM}$. High glucose levels and a PKC agonist activated p38 kinase, and a PKC inhibitor, GF109203X, prevented its activation. However, p38 kinase activation by mannitol or tumor necrosis factor- $\alpha$ was not inhibited by GF109203X. Changes in PKC isoform distribution after exposure to $16.5 \mathrm{mM}$ glucose in SMC suggested that both PKC$\beta 2$ and PKC- $\delta$ isoforms were increased. Activities of $\mathrm{p} 38$ kinase in PKC- $\delta$ - but not PKC- $\beta 1$-overexpressed SMC were increased compared with control cells. Activation of p38 kinase was also observed and characterized in various vascular cells in culture and aorta from diabetic rats. Thus, moderate hyperglycemia can activate $\mathrm{p} 38$ kinase by a PKC- $\delta$ isoform-dependent pathway, but glucose at extremely elevated levels can also activate $\mathrm{p} 38$ kinase by hyperosmolarity via a PKC-independent pathway.
\end{abstract}

J. Clin. Invest. 103:185-195 (1999).

\section{Introduction}

The results of the Diabetes Control and Complications Trial (1) have shown that strict glycemic control can prevent the onset and progression of diabetic complications. Several hypotheses such as hyperosmolarity, glycation end products, oxidant formation, abnormality of sorbitol and myoinositol metabolism, and diacylglycerol (DAG)-protein kinase $\mathrm{C}$ (PKC) activation (2-6) have been proposed to explain the various pathologic changes induced by hyperglycemia. It is likely that glucose and its metabolites mediate their adverse effects by altering the various signal transduction pathways, which are used by vascular cells to perform their functions and to maintain cellular integrity. We and others (6-16) have recently identified that the activation of $\mathrm{PKC}$, especially the $\beta$ isoforms, could be responsible for some of the vascular dysfunctions observed in the diabetic state. Some of these changes in the vascular cells are increases in contractility, cellular proliferation, permeability, and extracellular matrix and cytokine production $(5,6)$. However, it has not been determined whether hyperglycemia and its metabolites can affect other signal transduction systems and/or the cellular targets of DAG-PKC activation.

Recently, several mitogen-activated protein (MAP) kinase signal transduction pathways have been characterized (17-38). Extensive studies have clarified that they are activated by multistep phosphorylation cascades after ligand-cell surface receptor binding and and that they trans- mit signals to cytosolic and nuclear targets (17). The classic MAP kinases, extracellular signal-regulated protein kinase (ERK)-1 and -2, are activated through Ras-dependent signal transduction pathway by hormones and growth factors, leading to cellular proliferation and differentiation by stimulating transcription factors that induce the expression of c-fos and other growth-responsive genes $(18,19)$. With respect to ERKs, Haneda et al. (20) recently showed that high glucose levels phosphorylated ERKs through PKC activation in rat glomeruli and mesangial cells.

In contrast, two additional parallel signal transduction pathways, c-jun $\mathrm{NH}_{2}$-terminal protein kinase (JNK) and p38 MAP kinases, have also been identified (21-38). These pathways are strongly activated by environmental stress factors including ultraviolet light $(22,23)$, oxidants $(25$, 26), lipopolysaccharide (27-29), osmotic stress (30-33), heat shock (34), and proinflammatory cytokines such as tumor necrosis factor- $\alpha$ (TNF- $\alpha$ ) and interleukin-1 (35-38), leading to alterations in cell growth, prostanoid productions, and other cellular dysfunctions $(39,40)$.

Because many similar stress factors as already mentioned here have been identified to be present in diabetes, it is reasonable to suspect that p38 MAP kinase activation could also be involved in mediating hyperglycemia's adverse effects. In this study, we have characterized the mechanisms by which elevation of glucose levels activated p38 MAP kinase in cultured vascular cells and aorta derived from diabetic rats. 
$a$

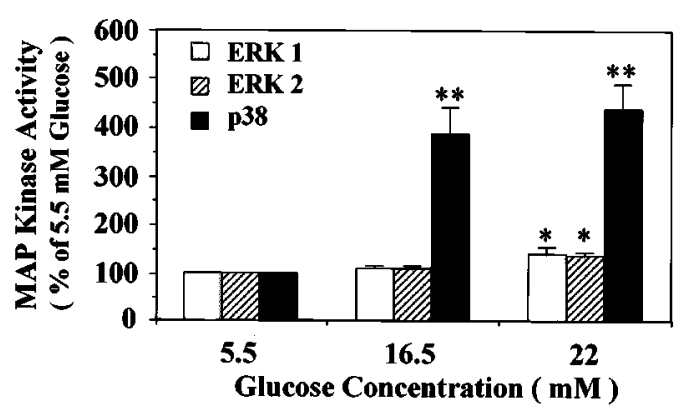

$b$

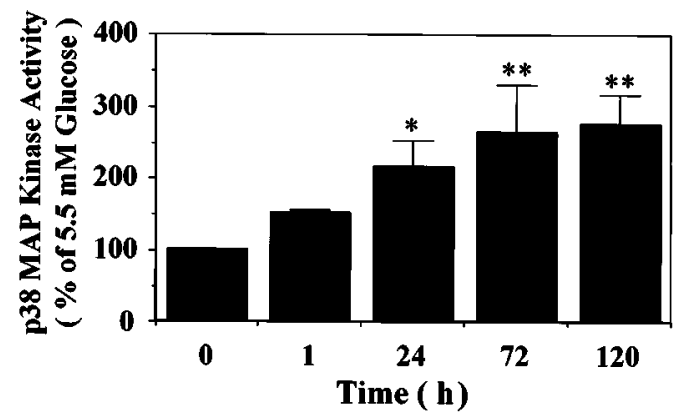

C

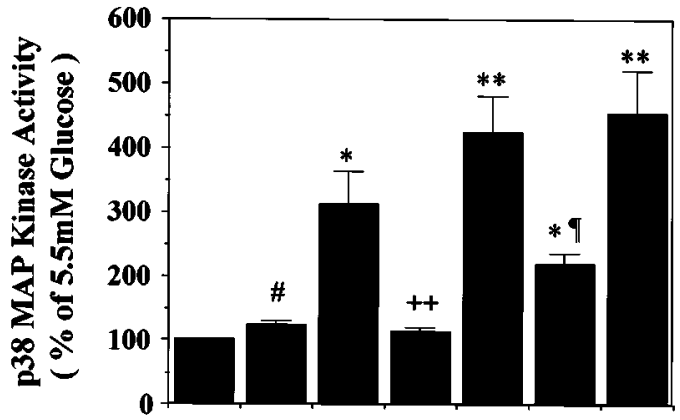

$\begin{array}{llllllll}\text { Glucose ( mM ) } & 5.5 & 5.5 & 11 & 5.5 & 16.5 & 5.5 & 22\end{array}$ Mannitol (mM) (-) $5.5 \quad(-) \quad 11 \quad(-) \quad 16.5$ (-)

\section{Figure 1}

(a) Effect of glucose on ERK-1, ERK-2, and p38 MAP kinase activations in rat aortic SMC. After $72 \mathrm{~h}$ of exposure to 5.5, 16.5, or $22 \mathrm{mM}$ glucose, the cells were lysed, and MAP kinase activities were quantitated by in vitro phosphorylation of MBP using [ $\gamma^{-32}$ ] ATP as described in Methods. The results were derived from three separate experiments, with duplicates performed in each experiment. Each bar represents the mean \pm SEM in $a, b$, and $c .{ }^{*} P<0.05,{ }^{* *} P<0.01$ vs. $5.5 \mathrm{mM}$ glucose. (b) Time course of 16.5 $\mathrm{mM}$ glucose on $\mathrm{p} 38 \mathrm{MAP}$ kinase activity. After the indicated time of incubation with $16.5 \mathrm{mM}$ glucose, the cells were lysed and p38 MAP kinase activity was quantitated as already described. The results were derived from four separate experiments, with duplicates performed in each experiment. ${ }^{*} P<0.05,{ }^{*} P<0.01$ vs. 0 h. (c) Effect of elevated glucose and mannitol levels on p38 MAP kinase activation. After $72 \mathrm{~h}$ of exposure to several concentrations of glucose or mannitol, the cells were lysed and p38 MAP kinase activity was quantitated as already described. The results were derived from three separate experiments, with duplicates performed in each experiment. ${ }^{*} P<0.05,{ }^{*} P<0.01$ vs. $5.5 \mathrm{mM}$ glucose; $\# P<0.05$ vs. $11 \mathrm{mM}$ glucose; ${ }^{++} P<0.01$ vs. $16.5 \mathrm{mM}$ glucose; $P<0.05$ vs. $22 \mathrm{mM}$ glucose. $E R K$, extracellular signal-regulated protein kinase; MAP, mitogenactivated protein; $M B P$, myelin basic protein; $S M C$, smooth muscle cells.

\section{Methods}

Materials. DMEM, FBS, calf serum (CS), transferrin, selenium, Lipofectin and Lipofectamine, and anti-PKC- $\varepsilon,-\gamma,-\theta$, and $-\zeta$ antibodies were purchased from GIBCO BRL (Grand Island, New York, USA). Antiphosphospecific p38 MAP kinase antibody and antiphosphospecific MAP kinase kinase (MKK)-3/MKK-6 were obtained from New England Biolabs Inc. (Beverly, Massachusetts, USA). Anti-p38 MAP kinase, ERK-2, PKC- $\alpha$, JNK, $\beta \mathrm{I}, \beta \mathrm{II}$, and $\delta$ antibodies were from Santa Cruz Biotechnology Inc. (Santa Cruz, California, USA). Antiphosphospecific JNK antibodies and anti-ERK-1 antibodies were obtained from Upstate Biotechnology Inc. (Lake Placid, New York, USA), and [ $\gamma^{-32}$ P]ATP and $\left[{ }^{3} \mathrm{H}\right]$ arachidonic acid from Du Pont Nen Research Products (Boston, Massachusetts, USA). The following items were purchased: polyvinylidene difluoride (PVDF) membrane from Novex (San Diego, California, USA); ECL kit from Amersham Life Sciences Inc. (Arlington Heights, Illinois, USA); PMA and bisindolylmaleimide I (GF109203X) from Calbiochem-Novabiochem Corp. (La Jolla, California, USA); recombinant human TNF- $\alpha$ from Pepro Tech Inc. (Rocky Hill, New Jersey, USA); protein ASepharose 6MB from Pharmacia Biotech AB (Uppsala, Sweden); protein assay kit from Bio-Rad Laboratories Inc. (Hercules, California, USA); phosphocellulose squares (P-81) from Whatman Institute (Maidstone, United Kingdom); and plasmid maxi kit from QIAGEN Inc. (Valencia, California, USA). LY333351 and cDNA plasmid to PKC- $\delta$ isoform was kindly provided by Lilly Research Laboratories (Indianapolis, Indiana, USA), and SB203580 by SmithKline Beecham Pharmaceuticals (Pittsburgh, Pennsylvania, USA). All other materials were from Fisher Scientific Co. (Pittsburgh, Pennsylvania, USA) and Sigma Chemical Co. (St. Louis, Missouri, USA).

Cell culture. Rat aortic smooth muscle cells (SMC) were harvested from male Sprague-Dawley rats (100-150 g) by the media explant technique and cultured in DMEM containing 10\% CS. Rat renal mesangial cells were isolated as described previously (16) and cultured in DMEM containing $5 \mathrm{mg} / \mathrm{ml}$ each of insulin, transferrin, and selenium with $20 \%$ FBS. Human aortic SMC were derived from minced pieces of human aorta and cultured in DMEM containing 20\% FBS. Bovine aortic SMC were harvested from calf aorta and cultured in DMEM containing 10\% CS. Bovine retinal pericytes were isolated as described previously (41) and cultured in DMEM containing 20\% FBS. The cells were used within 10 passages for the following studies.

Assay of MAP kinase activity. Subconfluent cultured cells were grown in DMEM containing $10 \%$ CS, and then the medium was changed to DMEM containing $1 \%$ CS with the indicated concentration of glucose or mannitol. After $48 \mathrm{~h}$ of incubation, the cells were incubated in DMEM containing $0.2 \%$ BSA with the same concentration of glucose or mannitol for another 24 h. The cells were washed three times with ice-cold PBS containing $1 \mathrm{mM}$ sodium orthovanadate, and then solubilized with $0.5 \mathrm{ml}$ of lysis buffer consisting of $20 \mathrm{mM}$ HEPES, $5 \mathrm{mM}$ $\mathrm{MgCl}_{2}, 25 \mathrm{mM} \mathrm{KCl}, 1 \mathrm{mM} \mathrm{Na}_{3} \mathrm{SO}_{4}, 1 \mathrm{mM}$ sodium molybdate, $10 \mathrm{mM} \beta$-glycerophosphate, $5 \mathrm{mM}$ tetrasodium pyrophosphate, $250 \mathrm{mM}$ sucrose, $1 \mathrm{mM}$ ATP, $2 \mathrm{mM}$ PMSF, $0.1 \mathrm{mg} / \mathrm{ml}$ aprotinin, and $1 \%$ Triton $\mathrm{X}-100$. The lysate was centrifuged at $14,000 \mathrm{~g}$ to remove insoluble materials, and the supernatant was incubated with anti-ERK-1, anti-ERK-2, or anti-p38 MAP kinase antibody overnight at $4^{\circ} \mathrm{C}$. Protein A-Sepharose $6 \mathrm{MB}$ was used to precipitate the immune complexes and was incubated for $2 \mathrm{~h}$ at $4^{\circ} \mathrm{C}$. The pellets were washed twice with ice-cold PBS and the assay buffer consisting of $20 \mathrm{mM}$ MOPS, $25 \mathrm{mM}$ $\beta$-glycerophosphate, $5 \mathrm{mM}$ EGTA, $1 \mathrm{mM} \mathrm{Na}_{2} \mathrm{SO}_{4}$, and $1 \mathrm{mM}$ DL-dithiothreitol (DTT). Then, $10 \mu \mathrm{l}$ each of the assay dilution buffer, $2 \mathrm{mg} / \mathrm{ml}$ myelin basic protein (MBP), $2 \mu \mathrm{M}$ protein kinase inhibitor, and a mixture of magnesium/ATP $(75 \mathrm{mM}$ $\mathrm{MgCl}_{2}$ and $\left.500 \mu \mathrm{M} \mathrm{ATP}\right)$ containing $10 \mu \mathrm{Ci}$ of $\left[\gamma^{-32} \mathrm{P}\right] \mathrm{ATP}$ were added to the reaction tube. After 10 min of incubation at room 
temperature, the kinase reaction was terminated by spotting 25 $\mu \mathrm{l}$ of reaction mixture on $2 \times 2-\mathrm{cm}$ phosphocellulose squares of Whatman P-81, and was washed three times with $0.75 \%$ phosphoric acid. MAP kinase-dependent phosphorylated substrates bound to the filterpapers were quantified by scintillation counting. For the immunoprecipitated p38 kinase activity, the ratio of specific to nonspecific counts (from $480 \mathrm{cpm}$ at basal to $2300 \mathrm{cpm}$ when stimulated) was $4.5: 1$ at $5.6 \mathrm{mM}$ of glucose.

Immunoblot analysis of phosphospecific p38 MAP kinase, JNK kinase, nonphosphorylated p38 MAP kinase, and phosphospecific MKK-3/MKK-6. Samples $(100 \mu \mathrm{g})$ were separated by $10 \%$ SDS-PAGE, transferred to PVDF membranes, and blocked overnight with PBS containing 0.1\% Tween-20 and 5\% BSA. The membranes were incubated with antiphosphospecific p38 or JNK MAP kinase and antiphosphospecific MKK$3 /$ MKK- 6 antibodies overnight at $4^{\circ} \mathrm{C}$, or with anti-nonphosphorylated p38 MAP kinase antibody for $1 \mathrm{~h}$ at room temperature. The blots were washed and then incubated with peroxidase-conjugated anti-rabbit immunoglobulins. After washing, sites of antibody binding were visualized using ECL Western blotting detection system and quantified using an image densitometer (Molecular Dynamics, Sunnyvale, California, USA). The variabilities of immunoblotting studies for each protein are shown in each figure. In general, Western blotting techniques can detect changes of $20 \%-30 \%$ in our studies.

In situ PKC activity assay. PKC activity was measured by using a modified in situ method described previously (42). Briefly, subconfluent rat SMC in 12-well culture plates were exposed to DMEM containing $1 \%$ CS with various concentrations of glucose or mannitol. After $48 \mathrm{~h}$ of incubation, the cells were incubated in DMEM containing $0.2 \%$ BSA with the same concentration of glucose or mannitol for another $24 \mathrm{~h}$. The cells were washed rapidly three times with $2 \mathrm{ml}$ of DMEM containing 20 mM HEPES ( $\mathrm{pH}$ 7.4), and then replaced with a salt solution consisting of 137 $\mathrm{mM} \mathrm{NaCl}, 5.4 \mathrm{mM} \mathrm{KCl}, 0.3 \mathrm{mM} \mathrm{Na}_{2} \mathrm{HPO}_{4}, 0.4 \mathrm{mM} \mathrm{KH}_{2} \mathrm{PO}_{4}, 5.5$ $\mathrm{mM}$ glucose, $10 \mathrm{mM} \mathrm{MgCl}_{2}, 25 \mathrm{mM} \beta$-glycerophosphate, $5 \mathrm{mM}$ EGTA, $2.5 \mathrm{mM} \mathrm{CaCl}_{2}, 20 \mathrm{mM}$ HEPES, $50 \mathrm{mg} / \mathrm{ml}$ digitonin, 100 $\mu \mathrm{M}$ ATP mixed with $\left[\gamma_{-32}{ }^{32}\right]$ ATP $(<1500 \mathrm{cpm} / \mathrm{pmol})$, and $100 \mu \mathrm{M}$ PKC-specific peptide substrate (RKRTLRRL) (43) for $15 \mathrm{~min}$ at room temperature. The kinase reaction was terminated with $5 \%$ (wt/vol; final concentration) TCA, spotted on $2 \times 2-\mathrm{cm}$ phosphocellulose squares of Whatman P-81, and washed three times with $0.75 \%$ phosphoric acid. Before being quantitated as described previously $(42,44)$, the ratios of total to peptide negative control PKC activities were usually greater than 5-10-fold, depending on the stimulant used.

Overexpression of PKC- $\delta$ isoform in rat aortic SMC. cDNA plasmid containing human PKC- $\delta$ isoform or $\beta$-galactosidase $c D N A$ was isolated by using plasmid maxi kit and ligated into multiple cloning site in a retroviral vector, $\mathrm{pBabe-Puro,} \mathrm{as} \mathrm{described} \mathrm{pre-}$ viously $(45,46)$. The cDNA $(10 \mu \mathrm{g})$ was transfected into BOSC23 cells via $60 \mu \mathrm{l}$ of Lipofectamine for $6 \mathrm{~h}$, and then the media was changed to DMEM containing $10 \%$ CS to remove Lipofectamine. After $48 \mathrm{~h}$, the supernatant was collected and sterilized by passing through $0.45-\mu \mathrm{m}$ filters, and then added to primary cultured rat aortic SMC with DMEM containing $10 \%$ CS with 4 $\mu \mathrm{g} / \mathrm{ml}$ hexadimethrine bromide (47). After another $48 \mathrm{~h}$, the cells were trypsinized and passaged at a 1:4 ratio in DMEM containing $10 \%$ CS with $10 \mu \mathrm{g} / \mathrm{ml}$ of puromycin. The colonies, which were resistant to puromycin, were cloned by ring isolation. After 10-14 days of culture, cells were tested for the expression of PKC isoforms by immunoblot analysis and activity assays. Three different clones of cells overexpressing PKC- $\delta$ isoforms derived from two separate retroviral infections were isolated, grown, and used for the described studies.

Immunoblot analysis of PKC isoforms. SMC were washed three times with ice-cold PBS and once with buffer consisting of 20 mM Tris-HCl, 2 mM EDTA, 0.5 mM EGTA, 1 mM PMSF, 1
$\mathrm{mM}$ DTT, $300 \mathrm{mM}$ sucrose, and $25 \mathrm{mg} / \mathrm{ml}$ leupeptin. PKC in the membranous and cytosolic fractions were partially purified using DEAE cellulose $(9,11)$, and then protein concentrations were determined by the method of Bradford (48). Partially purified PKC fractions were separated by $8 \%$ SDS-PAGE, transferred to PVDF membranes, and blocked overnight with PBS containing $0.1 \%$ Tween- 20 and $5 \%$ BSA. The membranes were incubated with several types of PKC isoform antibodies for $1 \mathrm{~h}$ at room temperature. The blots were washed and then were incubated with peroxidase-conjugated anti-rabbit immunoglobulins. Sites of antibody binding were visualized using an ECL Western blotting detection system (Amersham Pharmacia Biotech, Buckinghamshire, United Kingdom) and quantified using an image densitometer.

Construction of replication-deficient adenovirus containing PKC- $\beta 1$ $c D N A$. Construction of a replication-deficient recombinant adenovirus for PKC- $\beta 1$ expression was carried out as described previously $(49,50)$. Essentially, mouse PKC- $\beta 1$ cDNA obtained from P. Ashendal (Purdue University, Indianapolis, Indiana, USA) was litigated into the adenoviral shuttle vector, pACCCMV, downstream of the CMV promoter and upstream of an SV40 polyA tail signal. This PKC- $\beta 1$-containing shuttle vector was then cotransfected with the E1A transcription factor-deficient adenoviral genomic vector JM17 into 293 E1A-trans-

$a$

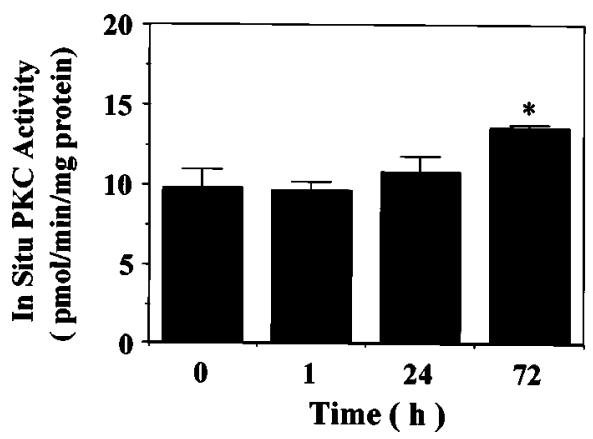

$\boldsymbol{b}$

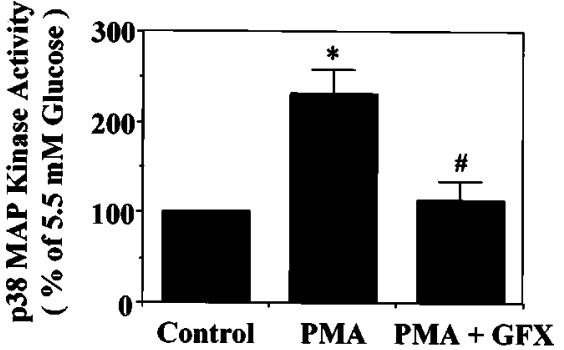

Figure 2

(a) Time course of glucose's $16.5 \mathrm{mM}$ effect on in situ PKC activity in rat aortic SMC. After indicated time of incubation with $16.5 \mathrm{mM}$ glucose, PKC activities were measured by in situ PKC assay using a PKC-specific peptide substrate, RKRTLRRL, in digitonin-permeabilized cells as described in Methods. ${ }^{*} P<0.05$ vs. 0 h. (b) Effect of regulators of PKC on p38 MAP kinase activation. After subculturing with $5.5 \mathrm{mM}$ glucose, the cells were treated or not treated with PMA $(100 \mathrm{nM})$ for 15 min or DMSO, treated with a PKC-specific inhibitor, GF109203X (GFX, $5 \mu \mathrm{M}$ ) prethanol, for $30 \mathrm{~min}$, and then lysed. P38 MAP kinase activity was quantitated by in vitro phosphorylation of MBP using $\left[\gamma^{32} \mathrm{P}\right] \mathrm{ATP}$ as described in Methods. GF109203X was solubilized with DMSO and PMA with ethanol, respectively, with final concentrations of DMSO and ethanol of $0.1 \%$. The results were derived from three separate experiments. ${ }^{*} P<0.05$ vs. $5.5 \mathrm{mM}$ glucose $(-),{ }^{\#} P<0.05$ vs. $5.5 \mathrm{mM}$ glucose treated with PMA. Each bar represents the mean \pm SEM. $P K C$, protein kinase $C$. 
formed cells by calcium phosphate precipitation $(49,50)$. Subsequent generation of recombinant adenovirus expressing PKC- $\beta 1$ (AdV-CMV-PKC- $\beta 1$ ) in 293 cell lysates was confirmed by Southern blot analysis. A control recombinant $\beta$-galactosidase adenovirus (AdV-CMV- $\beta$ Gal) was similarly generated (49, 50). Recombinant adenoviruses were purified by cesium chloride gradient centrifugation, desalted, and then assayed for infectivity in a 293-cell plaque assay. Purified adenovirus stocks $\left(10^{12} \mathrm{pfu} / \mathrm{ml}\right)$ were stored in $20 \%$ glycerol at $-80^{\circ} \mathrm{C}$. Adenoviral mediated gene transfer to confluent SMC was performed by a 1 -h adenoviral infection of $10^{9} \mathrm{pfu} / \mathrm{ml}$ at $37^{\circ} \mathrm{C}$ in DMEM containing $10 \% \mathrm{CS}$, as described previously $(49,50)$.

Release of $\left[{ }^{3} \mathrm{H}\right]$ arachidonic acid in rat aortic SMC. Subconfluent SMC were cultured in DMEM containing 1\% CS with $5.5 \mathrm{mM}$ glucose, $16.5 \mathrm{mM}$ glucose, and $22 \mathrm{mM}$ glucose, or $5.5 \mathrm{mM}$ glucose plus $16.5 \mathrm{mM}$ mannitol. After $48 \mathrm{~h}$ of incubation, the cells were labeled with $0.5 \mathrm{mCi} / \mathrm{ml}\left[{ }^{3} \mathrm{H}\right]$ arachidonic acid for $20 \mathrm{~h}$ at $37^{\circ} \mathrm{C}$. Then, media was replaced with $0.5 \mathrm{ml}$ of fresh media, incubated for $1 \mathrm{~h}$, and collected. The amount of $\left[{ }^{3} \mathrm{H}\right]$ arachidonic acid was determined as described previously (52).

Preparation of total lysate from rat aorta. Male Sprague-Dawley rats $(\sim 250 \mathrm{~g})$ were used for this procedure. Diabetes in rats was induced by a single intravenous injection of sterile streptozotocin (STZ) $(50 \mathrm{mg} / \mathrm{kg}$ body weight) solubilized with $20 \mathrm{mM}$ citrate buffer ( $\mathrm{pH} 4.5$ ). The control rats were also subjected to the same procedure without STZ. After $48 \mathrm{~h}$ of the injection, diabetes was confirmed by blood glucose levels exceeding $200 \mathrm{mg} / \mathrm{dl}$. The levels of blood glucose and body weight were monitored every 2 days for 6 weeks, and occasional insulin was given to prevent glucose level from exceeding $400 \mathrm{mg} / \mathrm{dl}$. All experimental procedures in the rats complied with the rules and regulations of the Committee on Ethics and Animal Research at the Joslin Diabetes Center. The thoracic aorta were rapidly removed and frozen in liquid nitrogen. After pulverizing the aorta, the samples were homogenized with $1 \mathrm{ml}$ of lysis buffer consisting of $20 \mathrm{mM}$ HEPES, 5 $\mathrm{mM} \mathrm{MgCl}_{2}, 25 \mathrm{mM} \mathrm{KCl}, 1 \mathrm{mM} \mathrm{Na}_{3} \mathrm{SO}_{4}, 1 \mathrm{mM}$ sodium molybdate, $10 \mathrm{mM} \beta$-glycerophosphate, $5 \mathrm{mM}$ tetrasodium pyrophosphate, $250 \mathrm{mM}$ sucrose, $1 \mathrm{mM}$ ATP, $2 \mathrm{mM}$ PMSF, $0.1 \mathrm{mg} / \mathrm{ml}$ aprotinin, and $1 \%$ Triton X-100 in a Dounce homogenizer for 30 strokes, and centrifuged. Protein contents of the supernatants were measured by Bradford's method (48).

Statistical analysis. Results were expressed as mean \pm SEM. Statistical significance was estimated by one-way ANOVA and Student Newman-Keuls test for comparison of several groups, and the differences were designated to be significant at $P<0.05$.

Figure 3

Effect of GF109203X on p38 MAP kinase activation in rat aortic SMC. After $72 \mathrm{~h}$ of exposure to several concentrations of glucose or mannitol, the cells were untreated, or treated with a PKC-specific inhibitor, GF109203X (GFX, $5 \mu \mathrm{M}$ ), for $30 \mathrm{~min}$; then, the cells were lysed as described in Methods. (a) p38 MAP kinase activity measured by the phosphorylation of MBP using [ $\gamma^{32}$ P] ATP. The results were derived from four separate experiments. ${ }^{*} P<0.01$ vs. $5.5 \mathrm{mM}$ glucose, ${ }^{*} P<0.05$ vs. $16.5 \mathrm{mM}$ glucose, ${ }^{+} P<0.05$ vs. $22 \mathrm{mM}$ glucose. (b) Expression of p38 MAP kinase by immunoblot analysis. The samples were separated by $10 \%$ SDS-PAGE, transferred to PVDF membranes, and blocked overnight. The membranes were incubated with antiphosphospecific p38 MAP kinase and anti-p38 antibody. The arrowhead shows the phosphorylation of $\mathrm{p} 38 \mathrm{MAP}$ kinase. The results were derived from three separate experiments. (c) p38 MAP kinase activity by the phosphorylation of MBP using $\left[\gamma^{-32}\right.$ ] $]$ ATP. The results were derived from three separate experiments, with each experiment performed in duplicate. ${ }^{*} P<$ 0.01 vs. $5.5 \mathrm{mM}$ glucose. Each bar represents the mean \pm SEM. PVDF, polyvinyldene difluoride.

\section{Results}

Effect of glucose on MAP kinase activation in rat aortic SMC. After 72 hours of exposure to $22 \mathrm{mM}$ glucose, ERK-1 and ERK-2 MAP kinase activities in rat aortic SMC were significantly increased to $138 \pm 15 \%$ and $135 \pm 9 \%$, respectively, compared with $5.5 \mathrm{mM}$ glucose (Fig. 1a). p38 MAP kinase activities were elevated to $386 \pm 54 \%$ and $437 \pm$ $51 \%$ when glucose levels were increased from 5.5 to 16.5 and $22 \mathrm{mM}$, respectively. The time course of p38 MAP kinase activation when incubated with $16.5 \mathrm{mM}$ glucose showed increases of $151 \pm 5 \%$ at 1 hour, $215 \pm 37 \%$ at 24 hours, $264 \pm 65 \%$ at 72 hours, and $274 \pm 42 \%$ at 120 hours, reaching a maximum after two to three days of incubation (Fig. 1b). JNK activation was also studied and did not differ in SMC cultured in 5.5 versus $16.5 \mathrm{mM}$ glucose, as measured by immunoblotting studies using antiphosphosphospecific JNK antibodies.

Because the effect of glucose on the activation of p38 MAP kinase was much greater than that of ERK-1 and 2 at all time points studied from 1 to 72 hours of incubation, further studies were focused on p38 MAP kinase. The effects of glucose and mannitol were compared

\section{$a$}

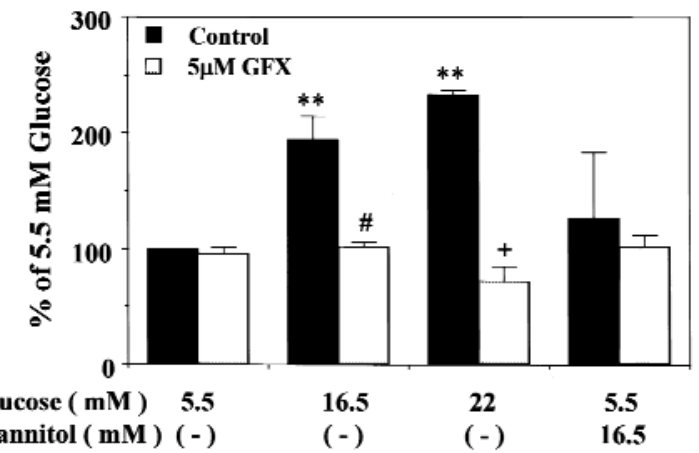

b Phosphospecific p38 MAP kinase

p38 MAP kinase

Glucose ( $\mathrm{mM}$ )

Mannitol ( $\mathrm{mM}$ )

$\operatorname{GFX}(5 \mu M)$

$\begin{array}{llllllll}5.5 & 5.5 & 16.5 & 16.5 & 22 & 22 & 5.5 & 5.5\end{array}$

$(-)(-)(-)(-)(-)(-) \quad 16.516 .5$

$(-)(+)(-)(+)(-)(+)(-)(+)$

C

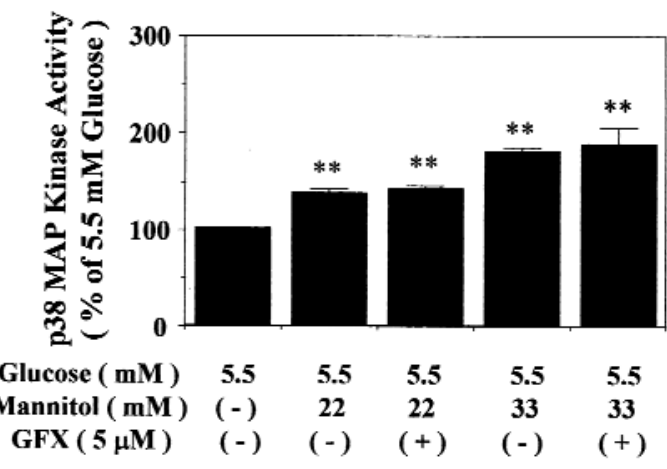


because hyperosmolarity is a known activator of p38 MAP kinase (30-33). The levels of p38 MAP kinase activation in rat aortic SMC were increased to $310 \pm 53 \%$ at $11 \mathrm{mM}, 421 \pm 58 \%$ at $16.5 \mathrm{mM}$, and $452 \pm 69 \%$ at $22 \mathrm{mM}$ glucose compared with activation levels at $5.5 \mathrm{mM}$ glucose. In contrast, the addition of $11 \mathrm{mM}$ mannitol to 5.5 $\mathrm{mM}$ glucose did not show any increase in p38 MAP kinase activation, whereas the addition of $16.5 \mathrm{mM}$ mannitol to $5.5 \mathrm{mM}$ glucose significantly increased p38 MAP kinase activities to $217 \pm 18 \%$ compared with 5.5 $\mathrm{mM}$ glucose alone (Fig. 1c). These results suggested that glucose levels at $16.5 \mathrm{mM}$ or lower activated p38 MAP kinase via metabolic and nonosmolar effect, but hyperosmolarity could have a significant role in p38 MAP kinase activation at $22 \mathrm{mM}$ or greater of glucose.

Effect of PKC on $p 38$ MAP kinase activation induced by glucose. To characterize a possible role for PKC in glucoseinduced p38 MAP kinase activation, the time course at $16.5 \mathrm{mM}$ glucose on in situ PKC activities was measured in rat aortic SMC. The activity was increased to $139 \%$ after 72 hours of exposure at $16.5 \mathrm{mM}$ compared with 0 hours (Fig. 2a). To support a possible role for PKC, we examined the effects of phorbol myristate acetate (PMA), a PKC agonist, and GF109203X, a general PKC-specific inhibitor, on p38 MAP kinase activation in rat aortic SMC (5-16). PMA increased p38 MAP kinase activity to $230 \pm 27 \%$ of the control, and the elevation was totally inhibited by GF109203X (Fig. 2b).

The relationship between p38 MAP kinase and PKC changes induced by glucose levels was studied (Fig. 3). Similar to Fig. 1, p38 MAP kinase activities in rat aortic SMC cultured with 16.5 and $22 \mathrm{mM}$ glucose were significantly increased to $194 \pm 21 \%$ and $233 \pm 4 \%$, respectively. However, the addition of $5 \mu \mathrm{M}$ GF109203X for 30 minutes inhibited p38 MAP kinase activities in cells cultured with both 16.5 and $22 \mathrm{mM}$ glucose to $102 \pm 3 \%$ or $72 \pm 14 \%$ of $5.5 \mathrm{mM}$ glucose alone, respectively. Mannitol at $16.5 \mathrm{mM}$ did not significantly increase p38 MAP kinase activity (Fig. $3 a$ ). The identity of p38 MAP kinase was also confirmed by immunoblot analysis of rat aortic SMC by quantifying the expressions of phosphospecific p38 MAP kinase at $16.5 \mathrm{mM}$ and $22 \mathrm{mM}$ glucose. A major band at $38 \mathrm{kDa}$ was detected that was comparable to the known molecular weight of p38 MAP kinase (22). Increased levels of the phosphorylated p38 MAP kinase were observed in the cells cultured with 16.5 and $22 \mathrm{mM}$ glucose but not with $16.5 \mathrm{mM}$ mannitol. Similar to Fig. $3 a$, the addition of GF109203X $(5 \mu \mathrm{M})$ reduced the levels of phosphorylated p38 MAP kinase (Fig. 3b). However, the protein levels of p38 MAP kinase were not changed in all cultured conditions (Fig. $3 b$ ). The role of PKC in the activation of 338 MAP kinase by hyperosmolarity was also characterized (Fig. 3c). Elevated osmolarity by the addition of 22 and $33 \mathrm{mM}$ mannitol to $5.5 \mathrm{mM}$ glucose increased p38 MAP kinase activities to $137 \pm 4 \%$ and $187 \pm 17 \%$ of $5.5 \mathrm{mM}$ glucose, respectively. However, the addition of GF109203X $(5 \mu \mathrm{M})$ did not affect the activation induced by the elevated levels of mannitol. Further examination of phosphospecific MKK-3/MKK6 activation in rat aortic SMC by immunoblot analysis did not show any changes by the addition of either high glucose or GF109203X (data not shown).
Table 1

Effect of glucose on p38 MAP kinase activation in different types o1 vascular cells

\begin{tabular}{lccc}
\hline Cell type & \multicolumn{3}{c}{$\begin{array}{c}\text { P38 MAP kinase activity } \\
\text { (\% of } 5.5 \mathrm{mM} \text { glucose) }\end{array}$} \\
& $5.5 \mathrm{mM}$ & $16.5 \mathrm{mM}$ & $22 \mathrm{mM}$ \\
Human aortic SMC & $100 \%$ & $198 \pm 17 \%^{\mathrm{A}}$ & $194 \pm 3 \%^{\mathrm{A}}$ \\
Bovine aortic SMC & $100 \%$ & $195 \pm 27 \%^{\mathrm{B}}$ & $198 \pm 46 \%^{\mathrm{B}}$ \\
Bovine retinal pericyte & $100 \%$ & $158 \pm 22 \%^{\mathrm{B}}$ & $147 \pm 32 \%^{\circ}$ \\
Rat glomerular mesangial cell & $100 \%$ & $163 \pm 30 \%^{\circ}$ & $170 \pm 31 \%^{\mathrm{B}}$
\end{tabular}

Results were expressed as mean \pm SEM. Human aortic SMC, $n=6$; bovine aortic SMC $n=4$; rat mesangial cell, $n=3$; bovine retinal pericyte, $n=4$. Culture conditions for each group of these cells were described in Methods. ${ }^{A} P<0.05$ vs. $5.5 \mathrm{mM}$ glucose. ${ }^{B} P<0.01$ vs. $5.5 \mathrm{mM}$ glucose. MAP, mitogen-activated protein; SMC, smooth muscle cells.

Elevation of glucose levels from 5.5 to $16.5 \mathrm{mM}$ activated p38 MAP kinase not only in rat aortic SMC but also in human and bovine aortic SMC to $198 \pm 17 \%$ and $195 \pm 27 \%$ of the respective controls (Table 1 ). Similar increases at $16.5 \mathrm{mM}$ were also observed in other microvessel vascular cells, namely bovine retinal pericytes and rat glomerular mesangial cells, with increases of $158 \pm 22 \%$ and $163 \pm 30 \%$, respectively, and at $22 \mathrm{mM}$, of $169 \pm 31 \%$ and $147 \pm 32 \%$, respectively.

We have reported previously $(10,12-17)$ that elevation of glucose levels in vivo or in vitro can increase or activate

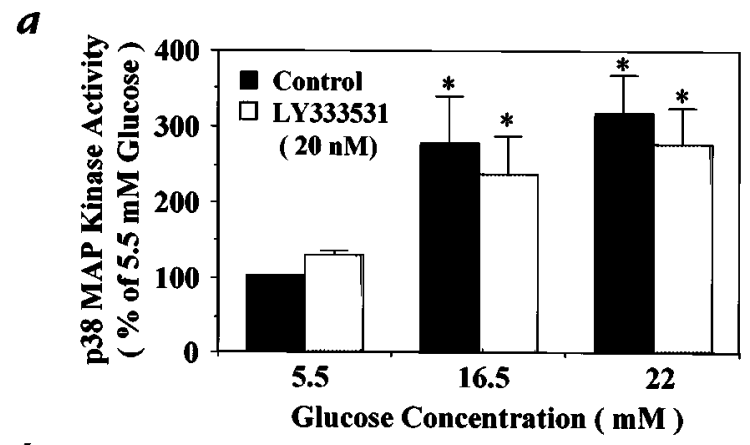

$b$

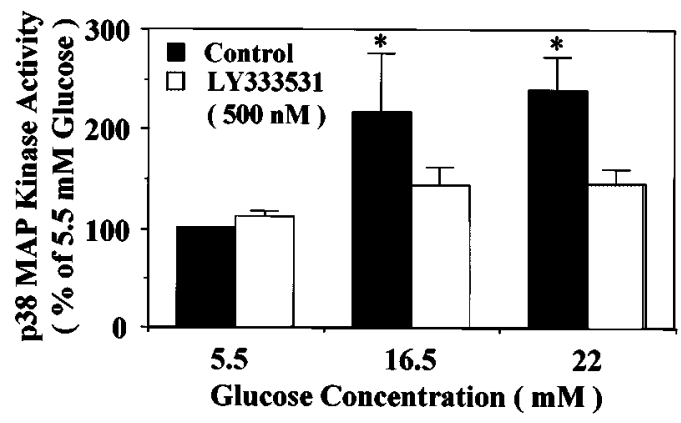

Figure 4

Effect of a PKC- $\beta$-specific inhibitor, LY333351, on p38 MAP kinase activity in rat aortic SMC. After 3 days of exposure to several concentrations of glucose or mannitol, the cells were untreated or treated with a PKCspecific inhibitor, LY333351 [(a) $20 \mathrm{nM}$ and (b) $500 \mathrm{nM}$ ], for $30 \mathrm{~min}$, and then lysed. The p38 MAP kinase activity was quantitated by the phosphorylation of MBP using [ $\gamma^{32}{ }^{32}$ P]ATP as described in Methods. LY333351 was solubilized with DMSO. The results were derived from four separate experiments, with each experiment performed in duplicate. Each bar represents the mean \pm SEM. ${ }^{*} P<0.05$ vs. $5.5 \mathrm{mM}$ glucose. 
PKC, particularly the $\beta$ isoforms, in the vascular cells. Thus, the effect of PKC- $\beta$ isoform selective inhibitor LY333351 on glucose-induced p38 MAP kinase activation was determined in rat aortic SMC cultured with 16.5 and $22 \mathrm{mM}$ glucose. The activities again exhibited increases of $163 \pm 30 \%$ and $169 \pm 31 \%$ compared with 5.5 $\mathrm{mM}$ glucose. The addition of $20 \mathrm{nM}$ LY333531, which we had reported previously (16) and have again determined to inhibit PKC- $\beta$ isoforms' autophosphorylation in SMC by $90 \%$ specifically, did not inhibit the glucoseinduced p38 MAP kinase activation. However, $500 \mathrm{nM}$ LY333531, which can inhibit multiple PKC isoforms (53), prevented the glucose-induced p38 MAP kinase activation, similar to GF109203X (Fig. 4b).

Effect of various $P K C$ isoforms on the activation of $p 38$ MAP kinase in rat aortic $S M C$. Results from the studies using a PKC- $\beta$ isoform inhibitor, LY333531, suggested that the activation of PKC isoforms other than $\beta$ isoforms might be involved (15). Analysis of primary culture of rat or bovine aortic SMC incubated with $16.5 \mathrm{mM}$ glucose suggested that both PKC- $\beta 2$ and $-\delta$ isoforms were increased. However, the amounts of PKC- $\delta$ expression in the primary cultures were difficult to quantify by immunoblot analysis because of the low levels of changes in the expression. Thus, we have stably overexpressed PKC- $\delta$ isoform in rat aortic SMC by using a retroviral vector containing the full-length cDNA of human PKC- $\delta$ isoform. As shown in Fig. $5 a$, the viral infected cells exhibited $30 \pm 11$-fold and $5.2 \pm 0.5$-fold increases in human PKC- $\delta$ proteins in the cytosolic and membranous fractions compared with those fractions in the control cells that were infected with the same retroviral vector without human PKC- $\delta$ cDNA. The PKC- $\delta$-overexpressed cells also increased total PKC activities to $409 \%$ of basal,

\section{Figure 5}

(a) Characterization of PKC isoform and activities in PKC- $\delta$ isoform-overexpressed cells. (b) Immunoblot analysis of PKC isoforms in PKC- $\delta$-overexpressed and the control cells containing the retroviral vector without PKC- $\delta$ cDNA derived from rat aortic SMC. The infection was performed using the retroviral vector pBabe-Puro, as described in Methods. After the vector with or without PKC- $\delta$, cDNA was transfected into BOSC23 cells via Lipofectamine, and the supernatant was filtered and added to primary cultured rat SMC for infection. Positive transfectants were selected using puromysin. PKC proteins in both membranous and cytosolic fractions were partially purified. The proteins were separated by $8 \%$ SDS-PAGE, and immunoblot analysis was performed using various types of antibodies on PKC isoforms as described in Methods. The results are derived from four separate experiments. Each bar represents the mean \pm SEM. ${ }^{*} P<0.05$, ${ }^{*} P<0.01$ vs. control cells at $5.5 \mathrm{mM}$ glucose; $\# P<0.05$ vs. PKC- $\delta$-overexpressed cells at $5.5 \mathrm{mM}$ glucose. (b) Effect of PKC- $\delta$ overexpression on p38 MAP kinase activity in rat aortic SMC. After $72 \mathrm{~h}$ of exposure to 5.5 $\mathrm{mM}$ or $16.5 \mathrm{mM}$ glucose, the cells were untreated or treated with a PKCspecific inhibitor, GF109203X (GFX, $5 \mu \mathrm{M}$ ), for $30 \mathrm{~min}$, and then lysed. The $\mathrm{P} 38$ MAP kinase activity was quantitated by the phosphorylation of MBP using $\left[\gamma^{32} \mathrm{P}\right] A T P$ as described in Methods. The results were derived from four separate experiments, with each experiment performed in duplicate. Each bar represents the mean \pm SEM. ${ }^{*} P<0.01$ vs. control at 5.5 mM glucose; ${ }^{\#} P<0.05,{ }^{\#} P<0.01$ vs. PKC- $\delta$-overexpressed cells at $5.5 \mathrm{mM}$ glucose; ${ }^{++} P<0.01$ vs. control at $16.5 \mathrm{mM}$ glucose; $P<0.01$ vs. PKC$\delta$-overexpressed cells at $16.5 \mathrm{mM}$ glucose. These results were derived from three different cloned populations of SMC overexpressing PKC- $\delta$ and by $426 \%$ when stimulated by PMA, compared with their own controls (Table 2).

Using both PKC- $\delta$-overexpressed and control cells, the effects of 5.5 and $16.5 \mathrm{mM}$ glucose on various PKC isoforms were identified by immunoblot analysis (Fig. $5 a$ ). Overexpression of PKC- $\delta$ isoform did not cause any significant change in either cytosolic or membranous fraction of PKC- $\alpha,-\beta I$, and $-\beta I I$ isoforms. In contrast, the expressions of PKC- $\beta$ II isoform in both PKC- $\delta$-overexpressed and control cells were significantly increased to $175 \%$ and $138 \%$, respectively, by exposure to $16.5 \mathrm{mM}$ glucose, compared with $5.5 \mathrm{mM}$ glucose, in the membranous fractions. No significant change was observed in the cytosolic fractions. The protein levels of PKC- $\delta$ isoform in the membranous fractions of both PKC- $\delta$-overexpressed and control cells were also significantly increased to $162 \%$ and $137 \%$, respectively, by exposure to $16.5 \mathrm{mM}$ glucose, compared with their own controls. Furthermore, the cytosolic protein levels also showed increases of $30 \%$ and $35 \%$, respectively.

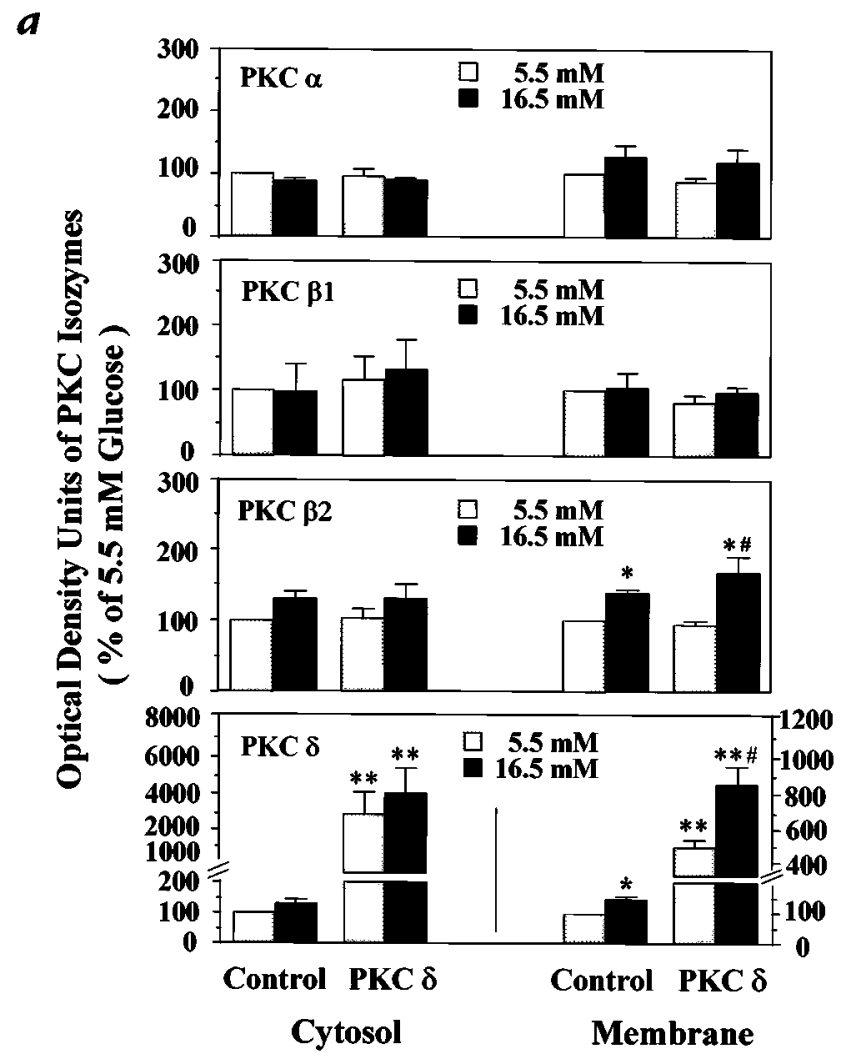

$b$

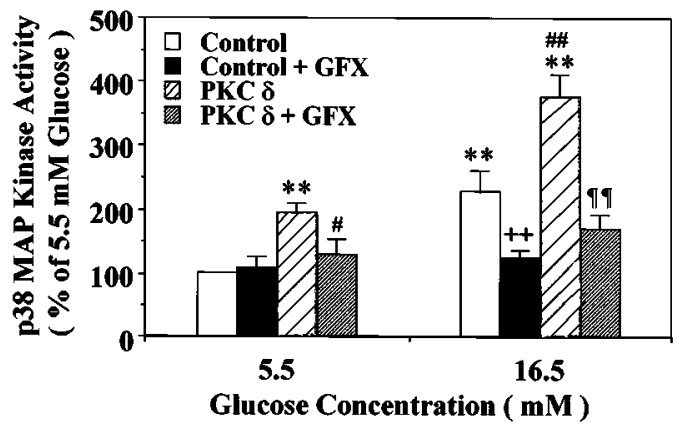


Although immunoblot analyses of PKC- $\varepsilon,-\gamma,-\theta$, and $-\zeta$ were also performed, no significant change in these PKC isoforms was noted (data not shown).

Activities of p38 MAP kinase were characterized after 72 hours of incubation with 5.5 or $16.5 \mathrm{mM}$ glucose. At $5.5 \mathrm{mM}$ glucose, p38 MAP kinase activities increased to $194 \%$ in the PKC- $\delta$-overexpressed cell compared with the control. When glucose concentration was increased to $16.5 \mathrm{mM}$, p38 MAP kinase activities in the control cell were elevated to $228 \pm 31 \%$ of $5.5 \mathrm{mM}$ glucose. Similarly, p38 MAP kinase activity in the PKC- $\delta$-overexpressed cell was significantly elevated to $165 \%$ in 16.5 $\mathrm{mM}$ glucose compared with its respective control. All increments of p38 MAP kinase activities were inhibited by the addition of GF109203X $(5 \mu \mathrm{M})$ (Fig. $5 b)$. To determine the isoform-specific actions of PKC- $\delta$ on p38 MAP kinase, we overexpressed PKC- $\beta 1$ isoform in the rat SMC by using a replication-deficient adenoviral vector containing cDNA of rat PKC- $\beta 1$ isoform or $\beta$-galactosidase. SMC infected with PKC- $\beta 1$ cDNA exhibited 30 - and 10 -fold increases in PKC- $\beta 1$ protein and PKC activities, respectively, compared with cells infected with $\beta$-galactosidase control (Fig. 6a). However, p38 MAP kinase activities, as measured by immunoblotting using antiphosphospecific p38 MAP kinase, did not differ between SMC infected with adenovirus containing PKC- $\beta 1$ or $\beta$-galactosidase cDNA (Fig. 6b).

Effect of TNF- $\alpha$ on $p 38$ MAP kinase activation in rat aortic $S M C$. To determine whether PKC activation has a similar effect on p38 MAP kinase activation when induced by either glucose or TNF- $\alpha$, we examined whether GF109203X, a PKC-specific inhibitor, can decrease the activations by these stimulants (Fig. 7). The addition of

a

1

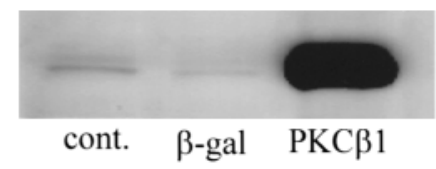

2

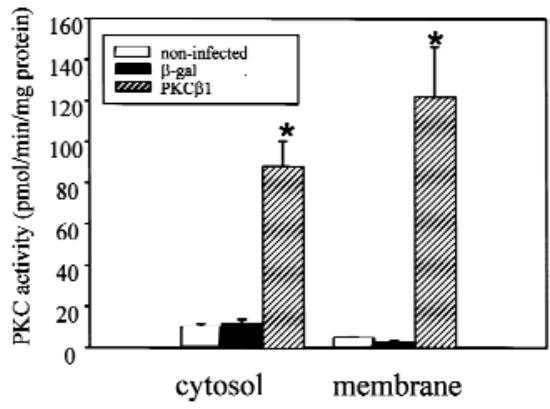

Table 2

In situ PKC activity assay in rat aortic SMC overexpressed PKC- $\delta$ isoform and its control cells

$\begin{array}{lc}\text { Cell type } & \begin{array}{c}\text { In situ PKC activity } \\ \text { (pmol/min/mg protein }\end{array} \\ \text { Control cell } & 9.40 \pm 0.84 \\ \text { Control cell + 100 nM PMA } & 38.30 \pm 2.08^{\mathrm{A}} \\ \text { PKC- } \delta \text {-overexpressed cell } & 38.49 \pm 0.86^{\mathrm{A}} \\ \text { PKC- } \delta \text {-overexpressed cell } & 163.01 \pm 2.95^{\mathrm{A}-\mathrm{C}} \\ +100 \mathrm{nM} \text { PMA } & \end{array}$

Results were expressed as mean $\pm \operatorname{SEM}(n=3)$. Culture conditions for each group of these cells were described in Methods. ${ }^{A P}<0.01$ vs. nonstimulated control cell. ${ }^{\mathrm{B}} P<0.01$ vs. PMA-stimulated control cell. ${ }^{C} P<0.01$ vs. nonstimulated $P K C-\delta$-overexpressed cell. $P K C$, prorein kinase $C$.

TNF- $\alpha$ significantly increased p38 MAP kinase activity in both 5.5 and $16.5 \mathrm{mM}$ glucose by $199 \pm 11 \%$ and 284 $\pm 37 \%$, respectively. Although GF109203X inhibited elevation of glucose-induced p38 MAP kinase activation, it did not decrease TNF- $\alpha$ 's effect.

Effect of a 38 MAP kinase-specific inbibitor, SB-203580, on arachidonic acid release in rat aortic SMC. One possible biologic consequence of glucose-induced p38 MAP kinase activation could be an increase in arachidonic acid production, because both hyperglycemia and p38 MAP kinase may activate phospholipase $\mathrm{A}_{2}$ activity $(38,42)$. Thus, the effect of glucose on arachidonic acid release was studied in rat aortic SMC. Changes of glucose level from 5.5 to 16.5 and $22 \mathrm{mM}$ increased arachidonic acid release to $139 \%$ and $172 \%$, respectively, which was not

b

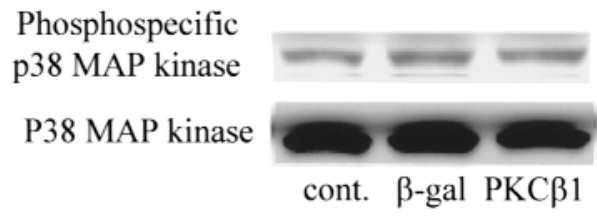

c

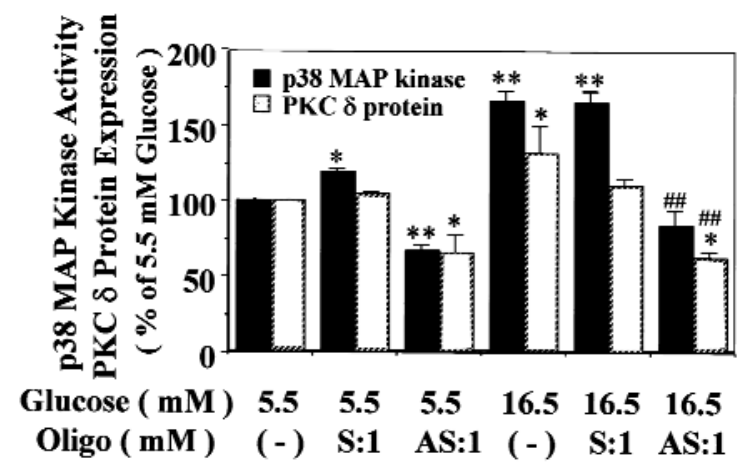

\section{Figure 6}

Effect of PKC- $\beta 1$ overexpression on p38 MAP kinase in rat aortic SMC. (a) Characterization of PKC- $\beta 1$ overexpression in rat aortic SMC after adenovirus infection. (1) Total cell lysate was isolated from cells that were not infected (cont.), or infected with Adv-CMV- $\beta$ Gal ( $\beta$-gal) or Adv-CMV-PKC- $\beta 1$ (PKC- $\beta 1)$. PKC- $\beta 1$ protein was detected by immunoblot analysis. (2) Four days after infection with adenovirus, cells were lysed and the cytosol and membrane proteins were fractionated by ultracentrifugation. The PKC activity was measured as described in Methods. Each bar represents the mean $+\mathrm{SD}(n=5)$. $P<$ 0.001 vs. noninfected and $\beta$-gal. (b) Activation of p38 MAP kinase in PKC- $\beta 1$-overexpressed SMC. Four days after infection with adenovirus, total cell lysate was isolated. The samples were separated by $10 \%$ SDS-gel, and the phosphorylation of p38 MAP kinase was detected by immunoblot analysis using phosphospecific p38 MAP kinase as described in Methods. The results were derived from three separate experiments. 


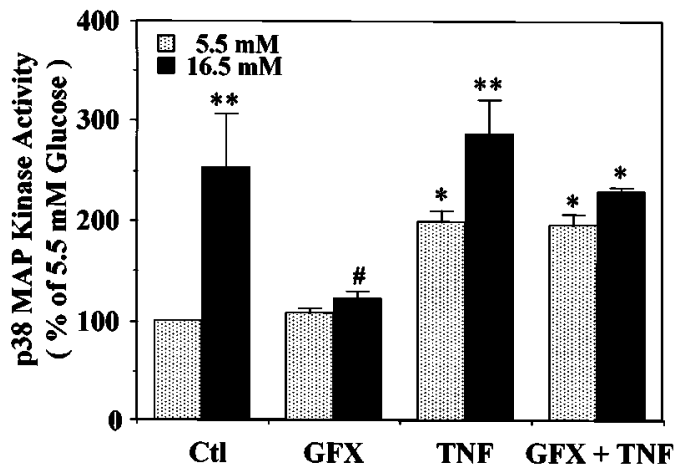

Figure 7

Effect of TNF- $\alpha$ and GF109203X on p38 MAP kinase activity in rat aortic SMC. After subculturing with $5.5 \mathrm{mM}$ or $16.5 \mathrm{mM}$ glucose, the cells were not treated or treated with TNF- $\alpha(100 \mathrm{nM})$ for 5 min after pretreatment with a PKC-specific inhibitor, GF109203X (GFX, $5 \mu \mathrm{M}$ ), for 30 $\mathrm{min}$, and then lysed. The p38 MAP kinase activity was quantitated by the phosphorylation of MBP using $\left[\gamma^{-32}\right.$ P]ATP as described in Methods. GF109203X was solubilized with DMSO and TNF- $\alpha$ with serum-free DMEM, respectively. The results were derived from three separate experiments, with each experiment performed in duplicate. Each bar represents the mean \pm SEM. ${ }^{*} P<0.05,{ }^{* *} P<0.01$ vs. $5.5 \mathrm{mM}$ glucose $(-) ;{ }^{*} P<0.05$ vs. $16.5 \mathrm{mM}$ glucose (-). TNF, tumor necrosis factor.

reproduced by $16.5 \mathrm{mM}$ mannitol and $5.5 \mathrm{mM}$ glucose (Fig. 8a). The addition of SB-203580 $(5 \mu \mathrm{M})$, an inhibitor of p38 MAP kinase (54), decreased the effect of $16.5 \mathrm{mM}$ glucose on arachidonic acid release completely (Fig. 8b).

Effect of diabetes on 738 MAP kinase activation in the aorta from control and diabetic rats. Because all the studies so far have been performed in cultured vascular cells, we have confirmed that p38 MAP kinase activities were also increased in the aorta of diabetic rats. Diabetes was induced by treatment with STZ, which increased blood glucose levels of the diabetic group from $93 \pm 2$ to $349 \pm 21 \mathrm{mg} / \mathrm{dl}(n=8)$ compared with control rats. The final body weights were $410 \pm$ 9 and $356 \pm 14 \mathrm{~g}$ for control and STZ diabetic rats, respectively. The protein levels and activations of p38 MAP kinase were characterized by immunoblot analysis with antibodies to both nonphosphorylated and phosphorylated p38 MAP kinase. Diabetes for six weeks increased the total protein level of p38 MAP kinase by 34\% and that of the phosphorylated p38 MAP kinase by more than threefold compared with the control (Fig. 9).

\section{Discussion}

A great deal of evidence supports the conclusion that hyperglycemia causes adverse effects on vascular cells possibly by a variety of mechanisms (2-5). Previously, we and others have documented (6-16) that one of these path-

\section{Figure 8}

Effect of elevated glucose levels and a p38 MAP kinase-specific inhibitor, SB-203580, on arachidonic acid release in rat aortic SMC. (a) After $48 \mathrm{~h}$ of exposure to various conditions of glucose and mannitol, the cells were labeled with $\left[{ }^{3} \mathrm{H}\right]$ arachidonic acid and further subcultured with the same conditions. The media were collected, and the amount of $\left[{ }^{3} \mathrm{H}\right]$ arachidonic acid released into the media was measured as described in Methods. Each bar represents the mean \pm SEM. ${ }^{*} P<0.05$ vs. 5.5 mM glucose. (b) SB-203580 was added to $0.5 \mathrm{ml}$ of the media and incubated for $30 \mathrm{~min}$ before the labeled media were collected for measurement of arachidonic acid release. Each bar represents the mean \pm SEM. ${ }^{*} P<0.01$ vs. $5.5 \mathrm{mM}$ glucose $(-),{ }^{\#} P<0.05$ vs. $16.5 \mathrm{mM}$ glucose. ways is due to the activation of PKC, involving mainly the PKC- $\beta$ isoforms. In this study, we have identified that p38 MAP kinase is an additional target in the signal transduction pathways, which are altered by hyperglycemia or diabetes both in vascular cultured cells and in vivo.

Recent studies have established that p38 MAP kinase can be activated by proinflammatory cytokines and environmental stresses such as ultraviolet light and osmotic shock but might not be affected by phorbol esters (33, 55). The mechanism of p38 MAP kinase activation is not identical to those of ERKs, because its signal transduction pathway is mediated by phosphorylated MKK- 3 and MKK-6 (33, 34, 55-57) and regulated by dual phosphorylation within the motif of Thr-Gly-Tyr $(36,55)$. Interestingly, our results showed that glucose levels from 11 to $16.5 \mathrm{mM}$ can activate p38 MAP kinase by different mechanisms from hyperosmolarity, which becomes significant only after glucose concentrations reached 22 $\mathrm{mM}$ or greater. The values of $\mathrm{p} 38$ MAP kinase were significantly increased in a dose- and time-dependent manner by elevated glucose concentrations compared with those at $5.5 \mathrm{mM}$ glucose; even at $11 \mathrm{mM}$ glucose, p38 MAP kinase activities were significantly increased. It is notable that p38 MAP kinase was activated to a much greater extent by glucose when compared with ERK-1 and ERK-2 (Fig. 1a). The activation of p38 MAP kinase could clearly be detected in the aorta from six-week diabetic rats, and the expression of phosphospecific p38 MAP kinase was increased by more than threefold compared with the control (Fig. 9). Interestingly, glucose at $22 \mathrm{mM}$ or greater can activate p38 MAP kinase by similar pathways as hyperosmolarity because the addition of $16.5 \mathrm{mM}$ mannitol to $5.5 \mathrm{mM}$ glucose also significantly increased p38 MAP kinase activities (Fig. 1c). These findings indicated that p38 MAP kinase can be activated by glucose levels commonly encountered in diabetic patients as well as by extremely high levels of glucose when the effects of osmotic shock are significant.

a

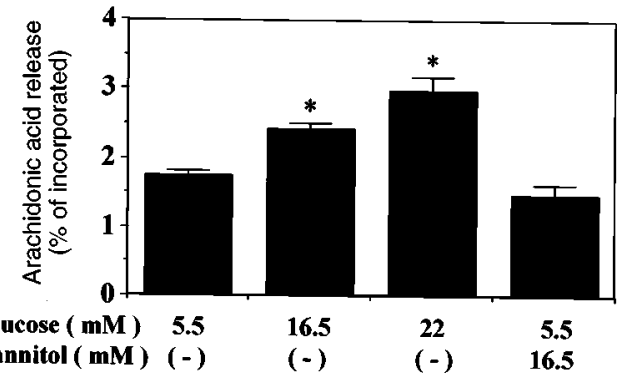

b

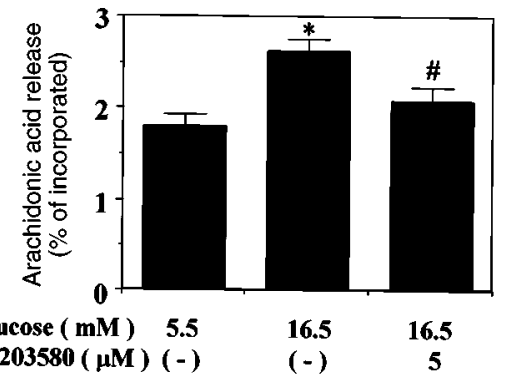


The time course of glucose-induced p38 MAP kinase activation showed that the activation required up to 24 hours after the changes of glucose levels (Fig. 1b). On the other hand, the time course of activation or increases in the amount of total PKC appeared to be slower than that of p38 MAP kinase activation (Fig. 2a), which could be the result of the difference in the sensitivities of the assays for PKC and MAP kinases. Hyperglycemia may activate or increase the amount of only certain PKC isoforms, which would not be reflected by measuring total PKC activity, whereas activation of various MAP kinases can be measured specifically for each ERK or p38 MAP kinase. Additional evidence in support of PKC activation to stimulate p38 MAP kinase was provided by the effect of PMA (Fig. $2 b$ ), and the inhibition of 38 MAP kinase activation by a PKC-specific inhibitor, GF109203X (Fig. $2 b$ and Fig. 3, $a$ and $b$ ). In contrast, p38 MAP kinase activation by mannitol at $22 \mathrm{mM}$ or greater was not affected by GF109203X (Fig. 3c), suggesting the involvement of non-PKC-mediated pathways. In addition, the phosphorylation of MKK3/MKK-6 was not affected by $16.5 \mathrm{mM}$ glucose, and TNF$\alpha$ did not show an additive effect with glucose or inhibition by GF109203X (Fig. 7). These findings indicated that the mechanisms of P38 MAP kinase activation induced by levels of less than $22 \mathrm{mM}$ glucose appear to involve PKC pathways and are different from activation induced by stress factors that include osmotic stress and proinflammatory cytokines such as TNF- $\alpha$.

Recently, MacFarlene et al. (57) have reported that elevation of glucose levels increased p38 MAP kinase activities in parallel with elevation of DAG levels by de novo synthesis in pancreatic $\beta$ cells. Thus, it appears that vascular cells and pancreatic $\beta$ cells share a common ability to increase DAG levels by de novo synthesis and activate both PKC and p38 MAP kinase. Most previous reports $(24,26,33,35,38)$ have not found a strong relationship between PKC and p38 MAP kinase activities when the activators are proinflammatory cytokines and environmental stresses. However, recently, two reports $(29,58)$ have suggested that the differentiation of leukocytes may require a PKC-dependent p38 MAP kinase activation. The combined results of our data and those cited earlier have clearly established that PKC activation can stimulate p38 MAP kinase cascade in the vascular cells.

Another interesting finding of this study is that hyperglycemia increased both PKC- $\beta$ and $-\delta$ isoforms in rat aortic SMC. We have reported previously $(9,11-16)$ that diabetes and hyperglycemia can increase different PKC isoforms depending on the source of vascular tissue, but $\mathrm{PKC}-\beta$ isoforms were consistently increased in all vascular tissues isolated from diabetic animals. In this study, the expressions of PKC- $\beta$ II were again shown to be significantly increased in the membranous fractions of both PKC- $\delta$-overexpressed cells and control cells by exposure to $16.5 \mathrm{mM}$ glucose (Fig. 5 a). However, p38 MAP kinase activation was not inhibited by $20 \mathrm{nM}$ of PKC- $\beta$ selective inhibitor LY333351 but was totally inhibited by GF109203X (Fig. 4a), indicating that PKC$\beta$ isoforms were not involved in a signal transduction pathway used by high glucose level to activate p38 MAP kinase. However, several lines of evidence suggest that the activation or increased amount of PKC- $\delta$ isoform

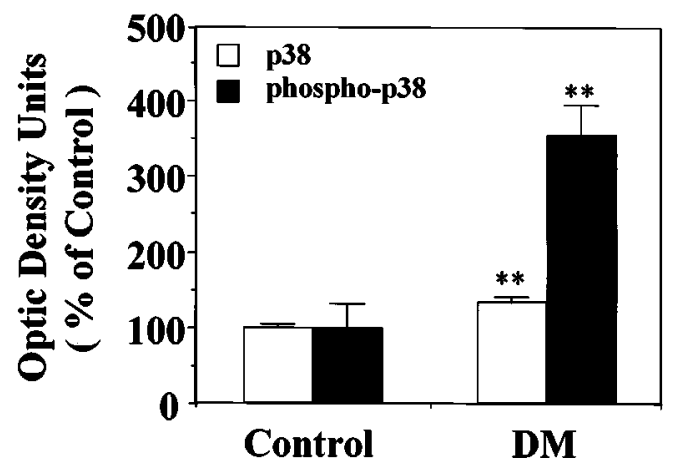

Figure 9

Effect of hyperglycemia on p38 MAP kinase activation in the aorta derived from control and diabetic rats. Rats were treated as described in Methods, and expressions of p38 MAP kinase and phosphospecific p38 MAP kinase were performed by immunoblot analysis. The optical density units by immunoblot analysis were measured with an image densitometer. Each bar represents the mean $\pm \operatorname{SEM}(n=8)$. ${ }^{*} P<0.01$ vs. the control.

might be responsible. First, the expressions of PKC- $\delta$ in both PKC- $\delta$-overexpressed and control cells in $16.5 \mathrm{mM}$ glucose were significantly increased by approximately $40 \%$ compared with the respective cells exposed to 5.5 mM glucose (Fig. $5 a$ ). Second, the activities of p38 MAP kinase in PKC- $\delta$-overexpressed cells were significantly elevated to $194 \%$ in $5.5 \mathrm{mM}$ and to $165 \%$ in $16.5 \mathrm{mM}$ glucose, compared with the control cells at these respective conditions. Third, all the increases in p38 MAP kinase activities induced by glucose or by overexpressing PKC$\delta$ isoform in the rat aortic SMC could be inhibited by GF109203X (Fig. 5b). Last, overexpression of PKC- $\beta 1$ isoform did not increase p 38 MAP kinase activity. These findings strongly suggested that hyperglycemia activates p38 MAP kinase in rat aortic SMC via increases in PKC$\delta$ isoform in an isoform-selective manner.

The possibility that hyperglycemia can also activate PKC$\delta$ isoform has been supported by our previous report (17) showing that PKC- $\alpha,-\beta 1$, and $-\delta$ isoforms were all activated or increased in the glomeruli of diabetic rats. Haller et al. (59) have reported that $20 \mathrm{mM}$ of glucose increased PKC$\delta$ immunoreactivity in the membranous fraction after six hours in rat aortic SMC, whereas the cytosolic fraction was not altered. PKC- $\delta$ isoform activation induced by glucose could have multiple biologic effects. Fukumoto et al. (60) reported that overexpression of PKC- $\delta$ isoform in cloned rat vascular SMC, A7r5, decreased cell proliferation by arresting cells in G1 via the inhibition of cyclin D1 and E. Interestingly, the growth rate of our SMC overexpressing PKC- $\delta$ isoform was also decreased to $31 \%$ compared with the control cells (data not shown). Lu et al. (61) demonstrated that $\mathrm{PKC}-\delta$ isoform regulated tumor-promoting effect stimulated by phorbol esters in the v-Src- or c$S r c$-overexpressed rat fibroblast 3Y1. On the other hand, PKC- $\delta$ isoform has been reported (62) to activate the MAP kinase/ERK kinase pathway in a manner dependent on cRaf and independent of Ras in COS1 cells (62), suggesting that it may enhance cell proliferation in some cases. Further studies will be needed to determine the role of PKC- $\delta$ isoform activation or increase induced by glucose in the functions and growth of SMC. 
One important biochemical consequence of increases in PKC- $\delta$ isoform in SMC induced by glucose appears to be p38 MAP kinase activation. This finding may have significance because it appears to occur in many vascular tissues involving arteries, capillaries, and mesangial cells. In addition, p38 MAP kinase activation can reflect gene expression by phosphorylating several transcription factors such as ATF-2 (37), CHOP-1 (63), MEF2C (64), and NFKB (65), resulting in either apoptosis or cell growth. Saklatvala et al. (66) also has reported that p38 MAP kinase may regulate platelet aggregation because SB-203580 can inhibit thromboxane generation. It is difficult to speculate which of the vascular abnormalities found in diabetic patients could be attributed to p38 MAP kinase activation. It is likely that changes of p38 MAP kinase will contribute to alteration in cell survival. Our results have shown that it could partly be responsible for increases in arachidonic acid production (Fig. 8), which we and others have reported previously $(17,44)$ to be induced by hyperglycemia. The results from this study using SB-203580 implied that the activation of p38 MAP kinase may be responsible for increased production of prostanoids in rat aortic SMC, because arachidonic acid is the precursor for synthesis of prostaglandins, thromboxanes, and leukotriens (67). However, the results are only suggestive because $S \beta$ 203580 may not be specific to p38 MAP kinase (68).

In summary, our study has identified p38 MAP kinase as a possible target in vascular cells, which can be activated by high glucose levels and diabetes. The activation of p38 MAP kinase by high glucose or diabetes is mediated by either PKC-dependent or -independent pathways, with the latter induced significantly by levels of hyperglycemia not usually observed clinically. At moderate and commonly encountered levels of hyperglycemia, p38 MAP kinase appears to be activated by PKC- $\delta$ isoform-dependent processes. It is likely that these changes in PKC- $\delta$ isoform and p38 MAP kinase induced by hyperglycemia will have biologic, and possibly pathologic, importance in the development of diabetic vascular complications.

\section{Acknowledgments}

The authors are grateful to D. Kirk Ways for human PKC- $\delta$ cDNA, and to Edward P. Feener (Joslin Diabetes Center) for his helpful suggestions during the preparation of this manuscript. Also, the authors thank National Disease Research Interchange for providing human arteries used for harvesting arterial SMC. This study was supported by National Institutes of Health grant EY05110 and Diabetes Education and Research Center grant DK36836.

1. The Diabetes Control and Complications Trial Research Group. 1993. The effect of intensive treatment of diabetes on the development and progression of long-term complications in insulin dependent diabetes mellitus. N. Engl.J. Med. 329:977-986.

2. Greene, D., Lattimer, S.A., and Sima, A.A.F. 1987. Sorbitol, phosphoinositides and sodium-potassium-ATPase in the pathogenesis of diabetic complications. N. Engl. J. Med. 316:599-606.

3. Brownlee, M., Cerami, A., and Vlassara, H. 1988. Advanced glycosylation end products in tissue and biochemical basis of diabetic complications. N. Engl.J. Med. 318:1315-1321.

4. Williamson, J.R., et al. 1993. Hyperglycemic pseudhypoxia and diabetic complications. Diabetes. 42:801-813.

5. Koya, D., and King, G.L. 1998. Protein kinase C activation and the development of diabetic complication. Diabetes. 47:859-866.

6. Craven, P.A., and DeRubertis, F.R. 1989. Protein kinase C is activated in glomeruli from streptozotocin diabetic rats. Possible mediation by glu- cose. J. Clin. Invest. 83:1667-1675

7. Craven, P.A., Davidson, C.M., and DeRubertis, F.R. 1990. Increase in diacylglycerol mass in isolated glomeruli by glucose from de novo synthesis of glycerolipids. Diabetes. 39:667-674.

8. Ayo, S.H., Radnik, R., Garoni, J.A., Troyer, D.A., and Kreisburg, J.I. 1991. High glucose increases diacylglycerol mass and activate protein kinase $\mathrm{C}$ in mesangial cell culture. Am. J. Physiol. 261:F571-F577.

9. Inoguchi, T., et al. 1992. Preferential elevation of protein kinase C isoform $\beta$ II and diacylglycerol levels in the aorta and heart of diabetic rats: differential reversibility to glycemic control by islet cell transplantation. Proc. Natl. Acad. Sci. USA. 89:11059-11063.

10. Williams, B., and Schreier, R.W. 1992. Characterization of glucoseinduced in situ protein kinase C activity in cultured vascular smooth muscle cells. Diabetes. 41:1464-1472.

11. Shiba, T., et al. 1993. Correlation of diacylglycerol level and protein kinase $\mathrm{C}$ activity in rat retina to retinal circulation. Am. J. Physiol. 265:E783-E793

12. Xia, P., et al. 1994. Characterization of mechanism for the chronic activation of diacylglycerol-protein kinase $\mathrm{C}$ pathway in diabetes and hypergalactocemia. Diabetes. 43:1122-1129.

13. Kunisaki, M., et al. 1995. Vitamin E prevents diabetes-induced abnormal retinal blood flow via the diacylglycerol-protein kinase C pathway. Am. J. Physiol. 269:E239-E246.

14. Kunisaki, M., Bursell, S.E., Umeda, F., Nawata, H., and King, G.L. 1995. Normalization of diacylglycerol-protein kinase $\mathrm{C}$ activation by vitamin $\mathrm{E}$ in aorta of diabetic rats and cultured rat smooth muscle cells exposed to elevated glucose levels. Diabetes. 43:1372-1377.

15. Ishii, H., et al. 1996. Amelioration of vascular dysfunctions in diabetic rats by an oral PKC $\beta$ inhibitor. Science. 272:728-731.

16. Koya, D., et al. 1997. Characterization of protein kinase $C \beta$ isoform activation on the gene expression of transforming growth factor- $\beta$, extracellular matrix components, and prostanoids in the glomeruli of diabetic rats. J. Clin. Invest. 100:115-126.

17. Seger, R., and Krebs, E.G. 1995. The MAPK signaling cascade. FASEB J. 9:726-798.

18. Kundra, V., et al. 1994. Regulation of chemotaxis by the platelet-derived growth factor receptor- $\beta$. Nature. 367:474-476.

19. Bilato, C., et al. 1995. Intracellular signaling pathways are required for rat vascular smooth muscle cell migration. J. Clin. Invest. 96:1905-1915.

20. Haneda, M., et al. 1997. Mitogen-activated protein kinase cascade is activated in glomeruli of diabetic rats and glomerular mesangial cells cultured under high glucose conditions. Diabetes. 46:847-853.

21. Cano, E., Hazzalin, C.A., and Mahadevan, L.C. 1994. Anisomycin-activated protein kinases $\mathrm{p} 45$ and $\mathrm{p} 55$ but not mitogen-activated protein kinases ERK-1 and -2 are implicated in the induction of c-fos and c-jun. Mol. Cell. Biol. 14:7352-7362.

22. Derijard, B., et al. 1994. JNK1: a protein kinase stimulated by UV light and Ha-Ras that binds and phosphorylates the c-jun activation domain. Cell. 76:1025-1037.

23. Han, J., Lee, J.D., Bibbs, L., and Ulevitch, R.J. 1994. A MAP kinase targeted by endotoxin and hyperosmolarity in mammalian cells. Science. 265:808-811.

24. Chen, Y.R., Wang, X., Templeton, D., Davis, R.J., and Tan, T.H. 1996. The role of c-jun $\mathrm{N}$-terminal kinase (JNK) in apoptosis induced by ultraviolet $\mathrm{C}$ and $\gamma$ radiation. Duration of JNK activation may determine cell death and proliferation. J. Biol. Chem. 271:31929-31936.

25. Liu, Y., Gorospe, M., Yang, C., and Holbrook, N.J. 1995. Role of mitogenactivated protein kinase phosphatase during the cellular response to genotoxic stress. Inhibition of c-jun $\mathrm{N}$-terminal kinase activity and AP1-dependent gene activation. J. Biol. Chem. 270:8377-8380.

26. Osborn, M.T., and Chambers, T.C. 1996. Role of the stress-activated/cjun $\mathrm{NH}_{2}$-terminal protein kinase pathway in the cellular response to adriamycin and other chemotherapeutic drugs. J. Biol. Chem. 271:30950-30955.

27. Heine, H., Ulmer, A.J., Flad, H.-D., and Hauschildt, S. 1995. Lipopolysaccharide-induced change of phosphorylation of two cytosolic proteins in human monocytes is prevented by inhibitors of ADP-ribosylation. $J$. Immunol. 155:4899-4908.

28. Lee, J.C., et al. 1994. A protein kinase involved in the regulation of inflammatory cytokine biosynthesis. Nature. 372:739-746.

29. Nick, J.A., Avdi, N.J., Gerwins, P., Johnson, G.L., and Worthen, G.S. 1996. Activation of a p38 mitogen-activated protein kinase in human neutrophils by lipopolysaccharide. J. Immunol. 156:4867-4875.

30. Shapiro, L., and Dinarello, C.A. 1995. Osmotic regulation of cytokine synthesis in vitro. Proc. Natl. Acad. Sci. USA. 92:12230-12234.

31. Moriguchi, T., Kawasaki, H., Matsuda, S., Gotoh, Y., and Nishida, E. 1995. Evidence for multiple activators for stress-activated protein kinase/c-jun amino-terminal kinases. J. Biol. Chem. 270:12969-12972.

32. Adler, V., Pincus, M.R., Polotskaya, A., Montano, X., and Friedman, F.K. 1996. Activation of c-jun- $\mathrm{NH}_{2}$-kinase by UV irradiation is dependent on p21ras. J. Biol. Chem. 271:23304-23309.

33. Stein, B., Brady, H., Yang, M.X., Young, D.B., and Barbosa, M.S. 1996. 
Cloning and characterization of MEK6, a novel member of the mitogenactivated protein kinase cascade. J. Biol. Chem. 271:11427-11433.

34. Rouse, J., et al. 1994. A novel kinase cascade triggered by stress and heat shock that stimulate MAPKAP kinase-2 and phosphorylation of the small heat shock proteins. Cell. 78:1027-1037.

35. Modur, V., Zimmerman, G.A., Prescott, S.M., and McIntyre, T.M. 1996. Endothelial cell inflammatory responses to tumor necrosis factor $\alpha$. J. Biol. Chem. 271:13094-13102.

36. Raingeaud, J., et al. 1995. Pro-inflammatory cytokines and environmental stress cause p38 mitogen-activated protein kinase activation by dual phosphorylation on tyrosine and threonine. J. Biol. Chem. 270:7420-7426.

37. Beyaert, R., et al. 1996. The p38/RK mitogen-activated protein kinase pathway regulates interleukin- 6 synthesis in response to tumor necrosis factor. EMBO J. 15:1914-1923.

38. Cuenda, A., Cohen, P., Buee-Scherrer, V., and Goedert, M. 1997. Activation of stress-activated protein kinase-3 (SAPK3) by cytokines and cellular stresses is mediated via SAPKK3 (MKK6): comparison of the specificities of SAPK3 and SAPK2 (RK/p38). EMBO J. 16:295-305.

39. Xia, Z., Dickens, M., Raingeaud, J., Davis, R.J., and Greenberg, M.E. 1995 Opposing effects of ERK and JNK-p38 MAP kinases on apoptosis. Science. 270:1326-1330.

40. Kramer, R.M., et al. 1996. p38 mitogen-activated protein kinase phosphorylates cytosolic phospholipase $\mathrm{A}_{2}\left(\mathrm{CPLA}_{2}\right)$ in thrombin-stimulated platelets. J. Biol. Chem. 271:27723-27729.

41. Nayak, R.C., Berman, A.B., George, K.L., Eisenbarth, G.S., and King, G.L. 1988. A monoclonal antibody (3G5)-defined ganglioside antigen is expressed on the cell surface of microvascular pericytes. J. Exp. Med. 167:1003-1015

42. Xia, P., Kramer, R.M., and King, G.L. 1995. Identification of the mechanism for the inhibition of $\mathrm{Na}^{+}, \mathrm{K}^{+}$-adenosine triphosphate by hyperglycemia involving activation of protein kinase $\mathrm{C}$ and cytosolic phospholipase $\mathrm{A}_{2}$.J. Clin. Invest. 96:733-740.

43. Yasuda, I., et al. 1990. A synthetic peptide substrate for selectivity assay of protein kinase C. Biochem. Biophys. Res. Commun. 166:1220-1227.

44. Lowry, O.H., Rosebrough, N.J., Farr, A.L., and Randall, R.J. 1950. Protein measurement with the folin phenol reagent. J. Biol. Chem. 193:265-275.

45. Reifel-Miller, A., et al. 1996. Protein kinase $\mathrm{C}$ isozymes differentially regulate promoters containing PEA-3/12-O-tetradecanoylphorbol-13acetate response element motifs. J. Biol. Chem. 271:21666-21671.

46. Morgenstern, J.P., and Land, H. 1990. Advanced mammalian gene transfer: high titer retroviral vectors with multiple drug selection markers and a complementary helper-free packaging cell line. Nucleic Acids Res. 18:3587-3596.

47. Pear, W.S., Nolan, G.P., Scott, M.L., and Baltimore, D. 1993. Production of high-titer helper-free retroviruses by transient transfection. Proc. Natl. Acad. Sci. USA. 90:8392-8396.

48. Bradford, M.M. 1976. A rapid and sensitive method of the quantitation of microgram quantities of protein utilizing the principle of protein-dye binding. Anal. Biochem. 72:248-254

49. Becker, T.C., BeltrandelRio, H., Noel, R.J., Johnson, J.H., and Newgard, C.B. 1994. Overexpression of hexokinase I in isolated islet of Langerhans via recombinant adenovirus. Enhancement of glucose metabolism and insulin secretion at basal but not stimulatory glucose levels. J. Biol. Chem. 269:21234-21238.

50. Becker, T.C., et al. 1994. Use of recombinant adenovirus for metabolic engineering of mammalian cells. Methods Cell Biol. 43:161-189.
51. Derijard, B., et al. 1995. Independent human MAP kinase signal transduction pathways defined by MEK and MKK isoforms. Science. 267:682-685.

52. Williams, B., and Schrier, R.W. 1993. Glucose-induced protein kinase C activity regulates arachidonic acid release and eicosanoid production by cultured glomerular mesangial cells. J. Clin. Invest. 92:2889-2896.

53. Jirousek, M.R., et al. 1996. (S)-13-[Dimethylamino)methyl]-10, 11, 14, 15tetrahydro-4.9:16, 21-dimetheno-1 $\mathrm{H}, 13 \mathrm{H}$-dibenzo [e, $\mathrm{k}]$ pyrrolo [3, 4h] $[1,4,13]$ oxadiazacyclohexadecene-1, 2 (2H)-dione (LY333351) and related analogues: isoform selective inhibitors of protein kinase $C \beta$. J. Med. Chem. 39:2664-2671.

54. Cuenda, A., et al. 1995. SB203580 is a specific inhibitor of MAP kinase homologue which is stimulated by cellular stresses and interleukin-1. FEBS Lett. 364:229-233.

55. Lin, A., et al. 1995. Identification of a dual specificity kinase that activates the Jun kinases and p38-Mpk2. Science. 268:286-290.

56. Rosette, C., and Karin, M. 1996. Ultraviolet light and osmotic stress: activation of the JNK cascade through multiple growth factor and cytokine receptors. Science. 274:1194-1197.

57. MacFarlene, W.M., et al. 1997. The p38/reactivating kinase mitogen-activated protein kinase cascade mediates the activation of the transcription factor insulin upstream factor 1 and insulin gene transcription by high glucose in pancreatic $\beta$-cells. J. Biol. Chem. 272:20936-20944.

58. Krump, E., Sanghera, J.S., Pelech, S.L., Furuya, W., and Grinstein, S. 1997. Chemotactic peptide $N$-formyl-met-leu-phe activation of p38 mitogenactivated protein kinase (MAPK) and MAPK-activated protein kinase-2 in human neutrophils. J. Biol. Chem. 272:937-944.

59. Haller, H., et al. 1995. High glucose concentrations and protein kinase C isoforms in vascular smooth muscle cells. Kidney Int. 47:1057-1067.

60. Fukumoto, S., et al. 1997. Protein kinase $C \delta$ inhibits the proliferation of vascular smooth muscle cells by suppressing G1 cyclin expression. J. Biol. Chem. 272:13816-13822.

61. Lu, Z., et al. 1997. Tumor promotion by depleting cells of protein kinase C $\delta$. Mol. Cell. Biol. 17:3418-3428.

62. Ueda, Y., et al. 1996. Protein kinase $\mathrm{C} \delta$ activates the MEK-ERK pathway in a manner independent of Ras and dependent on Raf. 1996. J. Biol. Chem. 271:23512-23519.

63. Wang, X., and Ron, D. 1996. Stress-induced phosphorylation and activation of the transcription factor CHOP (GADD153) by p38 MAP kinase. Science. 272:1347-1349.

64. Ha, J., Jiang, Y., Li, Z., Kravchenko, V.V., and Ulevitch, R.J. 1997. Activation of the transcription factor MEF2C by the MAP kinase p38 in inflammation. Nature. 386:296-299.

65. Vanden-Berghe, W., et al. 1998. p38 and extracellular signal-regulated kinase mitogen-activated protein kinase pathways are required for nuclear factor-kappaB p 65 transactivation mediated by tumor necrosis factor. J. Biol. Chem. 273:3285-3290.

66. Saklatvala, J., et al. 1996. Role for p38 mitogen-activated protein kinase in platelet aggregation caused by collagen or a thromboxane analogue. J. Biol. Chem. 271:6586-6589.

67. Guan, Z., Baier, L.D., and Morrison, A.R. 1997. p38 mitogen-activated protein kinase down-regulates nitric oxide and up-regulates prostaglandin $\mathrm{E}_{2}$ biosynthesis stimulated by interleukin-1 $\beta$. J. Biol. Chem. 272:8083-8089.

68. Whitmarsh, AJ., Yang, S.H., Sharrocks, A.D., and Davis, R.J. 1997. Role of p38 and JNK mitogen-activated protein kinases in the activation of ternary complex factors. Mol. Cell. Biol. 17:2360-2371. 